\title{
Prevalence of Depression amongst Caregivers of Stroke Patients Attending Hospital Universiti Sains Malaysia.
}

\author{
Azwanis Bnti Abdul Hadi ${ }^{1}$, Hafizah Binti Pasi ${ }^{2}$, Nivin Essam Eldin Abd Alla Yousef ${ }^{1}$ \\ ${ }^{1}$ Department of Family Medicine, International Islamic University Malaysia Kuantan \\ ${ }^{2}$ Department of Community Medicine, International Islamic University Malaysia Kuantan
}

\begin{abstract}
Introduction: Caregiving for stroke patients is a challenging task both emotionally and physically. Studies have shown that caregiving can affect caregivers' wellbeing that could lead to depression. Objective: This study was carried out to determine the prevalence and associated risk factors of depression amongst caregivers of stroke patients attending Hospital Universiti Sains Malaysia (HUSM) in Kelantan over a 6 month period. Methodology: This is a cross sectional study at the primary care clinic in HUSM over a period of 6 months. A total of 116 caregivers of medically documented stroke patients who fulfilled the inclusion and exclusion criteria were recruited via convenience sampling. The brief patient health questionnaire (PHQ-9) were used to assess their depression. Descriptive statistics and bivariable analysis was used using SPSS version 23.Results: $63.8 \%$ of the caregivers of stroke patients are depressed. Caregiver's burden, ethnicity and patient's ethnicity were found to be significant associated risk factors for depression.Conclusion: Screening for depression in caregivers especially those with risk factors must be carried out in the clinic in order to detect and intervene early. Coping mechanisms especially in the religious aspect should be elicited in future studies.
\end{abstract}

KEYWORDS: caregiver, depression, stroke, Malaysia

\section{INTRODUCTION}

According to WHO $(2003)^{1}$, stroke is a leading cause of adult disability. As mortality rate declines, the number of stroke survivors with impairments and disabilities increased. About two thirds of acute stroke patients will survive the initial stroke and about $50 \%$ of them are disabled because of persistent neurological impairment. ${ }^{2}$

In Malaysia a large portion of disabled stroke survivors live at home and is supported by informal caregivers who are usually their family members. Stroke survivors rely heavily on their caregivers' support for daily living activities as well as emotional and informational support. ${ }^{3}$ In addition to the primary impact of stroke, stroke survivors often suffer from a number of physical and psychosocial complications. ${ }^{2,3,9,10,11}$ Therefore the risk of caregivers developing low mood and even depression is high. Not only do caregivers have to deal with the stroke patients' difficulties in mobility, self-care, and communication, but also their cognitive impairment, depression, and personality changes. ${ }^{4}$ Because of the severity of stroke and the prevalence of post-stroke complications, as well as the sheer number of stroke survivors requiring care, the stress experienced by caregivers of stroke patients may be

Corresponding author:

Azwanis Binti Abdul Hadi, Department of Family Medicine

Kulliyyah of Medicine

International Islamic University Malaysia

Jalan Sultan Ahmad Shah, 25200 Kuantan, Pahang

Email: azwanis@iium.edu.my substantial. These caregivers may have additional demands from other aspects of their lives, such as having to take care of their own children as well or they may have their own health problems. ${ }^{3}$

There is concern that the level of strain experienced by caregivers of any chronic illnesses may further affect their own well-being and health. A local study done showed that the prevalence of depression among caregivers of patients with dementia is $17.3 \%,{ }^{5}$ while a study in Japan ${ }^{6}$ among caregivers of stroke patients showed a prevalence as high as $52 \%$. Both dementia and stroke are chronic illnessed with high caregiver dependency. However, the higher prevalence of depression among stroke caregivers could be because of the additional physical disability caused by stroke. Therefore, identification of determinants of caregiver's depression will help identify the caregiver at risk for physical or mental health problems. ${ }^{4}$

The purpose of this study was to investigate the prevalence and associated risk factors of depression among caregivers of stroke patients. This research hopes to provide more awareness to healthcare providers about the caregivers at risk of depression.

\section{METHODOLOGY}

\section{Ethical consideration}

Ethical approval was obtained from the Universiti Sains Malaysia Research Ethics Committee, Health Campus (USMKK/PPP/JEPeM [257.4.93.70]). Each 
IMJM Volume 17 Special Issue No 2

caregiver was given a study information sheet and a written consent was obtained prior to their participation.

\section{Study design, population and sampling method}

This was a cross sectional study on the caregivers of medically documented stroke patients which was carried out over a period of six months from December 2012 to May 2013 at the primary care clinic in HUSM. A total of 116 caregivers who accompanied the stroke patients were selected using convenience sampling. If there were more than one caregiver accompanying the patient, the caregiver who was the most involved in the caring of the patient was selected. In this study, caregivers were defined as a person who provides care for a patient with stroke be it physically, psychologically, socially or financially. Inclusion criteria were caregivers of patients with stroke as documented in the medical records; age 18 years and above; and who are able to understand Malay or English. Caregivers who were already providing support to patient prior to stroke were excluded.

\section{Study tool}

This study used a self-administered questionnaire which consisted of three $s$ ections. Section A: the demographic information of the patient and caregiver, Section B: the brief Patient Health Questionnaire (PHQ-9) and Section C: the Zarit Burden Interview (ZBI).

The brief PHQ-9, is a shorter alternative version of the PHQ. It is a self-administered tool that contains 9 items from the depression module of the full PHQ which focuses on the diagnostic criteria for DSM-IV depressive disorders. PHQ-9 scores of 5, 10, 15 and 20 represents mild, moderate, moderately severe and severe depression respectively. The Malay version of the $\mathrm{PHQ}-9$ is found to be a valid and reliable tool to be used in primary care in Malaysia. ${ }^{7}$

The $Z B I$ is used to measure the caregiver's perceived burden of providing care. Item scores are added up to give a total score ranging from 0 to 88 , with higher scores indicating greater burden. Scores of < 30, 30-59 and 60-88 indicates mild, moderate and high burden respectively. The questions focused on major areas such as caregiver's health, psychological well-being, finances, social life and the relationship between the caregiver and the patient. The Malay version is the translated version of the original by Choo et $\mathrm{al}^{8}$ which was validated by $\mathrm{Tn}$ Zailina et al in her dissertation. ${ }^{5}$ The reliability was found to be good. Therefore, this questionnaire is also suitable to be used among Malay majority population.

\section{Statistical Analysis}

Data were entered and analysed using the IBM SPSS for Windows version 23.0. Descriptive and bivariate statistics were used whenever appropriate.
A total of 130 caregivers were recruited in this study. The recruitment of the subjects was performed at the outpatients' clinic HUSM. 14 caregivers did not complete the interview as they were called into the consulting room. So, the drop out for this study was $10.8 \%$. The response rate was considered $89.2 \%$ in this study.

\section{Stroke patients' profile}

$51.7 \%$ of stroke patients were males with $87.1 \%$ Malays and $61.2 \%$ were not bedbound. The age range was between 42-92 years old with a mean age of $67.13 \pm 10.3$ years old.

\section{Caregivers' profile}

Almost $60.0 \%$ of caregivers were females with $87.1 \%$ of them Malays. $61.2 \%$ of the caregivers received secondary education level and $81.0 \%$ were married. The age range was between 18-84 years old with a mean age of $46.6 \pm 15.8$ years old. Their sociodemographic characteristics are summarized in Table 1.

Table 1 :Sociodemographic characteristics of caregivers

\begin{tabular}{|c|c|}
\hline Variables & $\mathrm{n}(\%)$ \\
\hline \multicolumn{2}{|l|}{ Caregiver's characteristics } \\
\hline Age (years) & $\begin{array}{l}46.6(15.7)^{*} \\
\text { Min: } 18 \\
\text { Max: } 84\end{array}$ \\
\hline Household income (RM) & $\begin{array}{l}\text { 1754.8 }(1841.7)^{*} \\
\text { Min: } 200 \\
\text { Max: } 15000\end{array}$ \\
\hline Care duration (months) & $\begin{array}{l}43.7(49.7)^{*} \\
\text { Min: } 1 \\
\text { Max: } 240\end{array}$ \\
\hline $\begin{array}{l}\text { Ethnicity } \\
\text { Malay } \\
\text { Chinese }\end{array}$ & $\begin{array}{l}101(87.1) \\
14(12.1) \\
1(0.9)\end{array}$ \\
\hline \multicolumn{2}{|l|}{ Others } \\
\hline $\begin{array}{l}\text { Gender } \\
\text { Female }\end{array}$ & $69(59.5)$ \\
\hline $\begin{array}{l}\text { Education } \\
\text { Primary } \\
\text { Secondary } \\
\text { Tertiary }\end{array}$ & $\begin{array}{l}13(11.2) \\
71(61.2) \\
32(27.6)\end{array}$ \\
\hline $\begin{array}{l}\text { Marital status } \\
\text { Married }\end{array}$ & $94(81)$ \\
\hline $\begin{array}{l}\text { Occupation status } \\
\text { Employed }\end{array}$ & $68(58.6)$ \\
\hline $\begin{array}{l}\text { Relationship } \\
\text { Wife } \\
\text { Husband } \\
\text { Son } \\
\text { Daughter } \\
\text { Other }\end{array}$ & $\begin{array}{l}32(27.6) \\
8(6.9) \\
26(22.4) \\
27(23.3) \\
23(19.8)\end{array}$ \\
\hline $\begin{array}{l}\text { Care duration (hours) } \\
>8 \text { hours }\end{array}$ & $78(67.2)$ \\
\hline
\end{tabular}




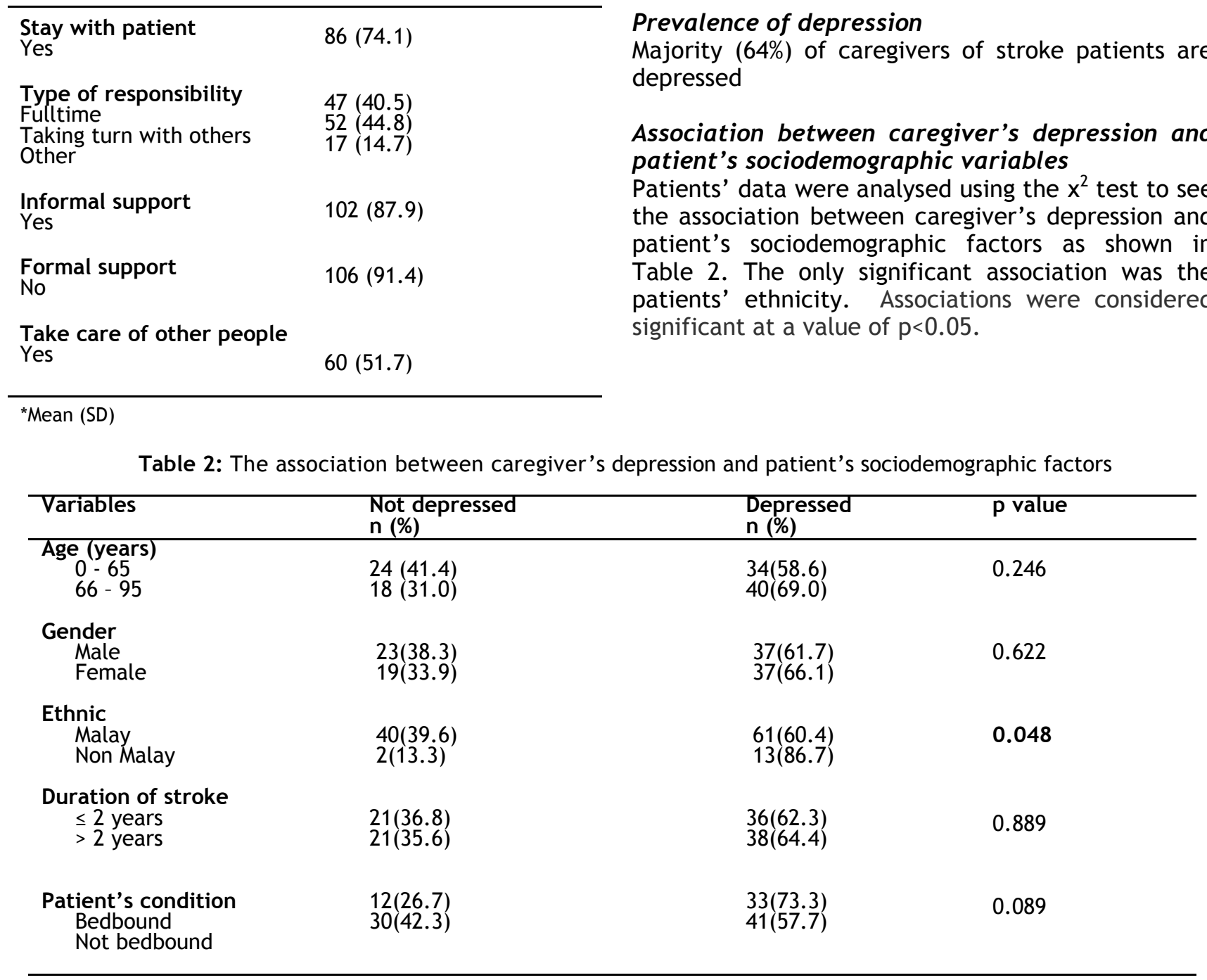

Chi square was used for the significance of the group difference Association between caregiver's depression and
caregiver's sociodemographic variables

Caregivers' data were analysed using the $x^{2}$ test to see the association between caregiver's depression and caregiver's sociodemographic as shown in Table 3. The two significant association was the caregiver's ethnicity and burden. Associations were considered significant at a value of $p<0.05$. Caregivers with moderate to severe burden had higher percentage of depression. After rechecking our data, all our caregivers looked after a patient from their own ethnic background so there is no cross ethnicity caregiving in this study. Caregivers' education level, marital status and hours in caregiving were not associated with depression.

\section{DISCUSSION}

Nearly $64 \%$ of the stroke patient caregivers in this study were found to be depressed as compared to Singapore ${ }^{9}$ and Japan. ${ }^{6}$ The discrepancy could be due to the different questions used to screen depression as well as different methodologies. It could also be due to the high burden that was felt among the caregivers of this study in which burden was a significant factor for their depression. Similar findings were reported by Morimoto et $\mathrm{al}^{6}$ whereby caregiver burden was significantly related to worsening mental health.

Findings from this study showed that caring after a non-Malay patient was a significant factor towards caregiver's depression. This study is unable to explain how patient's ethnicity is associated with caregiver's depression. However, several studies have suggested that a complication of stroke, Post Stroke Emotional Incontinence (PSEI) is relatively common among Chinese patients. ${ }^{10,11}$ PSEI is a complication where the patient could either laugh or cry suddenly uncontrollably, and has been linked to affect a patient's Health Related Quality of Life (HRQOL) and could lead to depression. ${ }^{11,12}$ However further studies among the Chinese population in Malaysia is recommended to explore this.

Non-Malays caregivers were also found to have higher percentage of depression. This finding is similar to a study carried out in Kuala Lumpur ${ }^{8}$ among caregivers of dementia patients. Her study found that the Chinese caregivers were the most affected. It is possible that the reason for such results could lie in the coping mechanism. Previous researches had found that ethnicity and culture played a significant role in the stress and coping process for family caregivers. ${ }^{16,18}$ A study in Hong 
Table 3: The association between depression and caregivers sociodemographic factors

\begin{tabular}{|c|c|c|c|}
\hline+2 & $\begin{array}{l}\text { Not depressed } \\
\mathrm{n}(\%)\end{array}$ & $\begin{array}{l}\text { Depressed } \\
\mathrm{n}(\%)\end{array}$ & P value \\
\hline $\begin{array}{l}\text { Caregivers age (years) } \\
\quad 0-65 \\
\quad 66-95\end{array}$ & $\begin{array}{c}37(35.6) \\
5(41.7)\end{array}$ & $\begin{array}{l}67(64.4) \\
7(58.3)\end{array}$ & 0.678 \\
\hline $\begin{array}{l}\text { Ethnic } \\
\text { Malay } \\
\text { Non Malay }\end{array}$ & $\begin{array}{l}40(39.6) \\
2(13.3)\end{array}$ & $\begin{array}{l}61(60.4) \\
13(86.7)\end{array}$ & 0.048 \\
\hline $\begin{array}{l}\text { Education } \\
\text { Lower } \\
\text { Higher }\end{array}$ & $\begin{array}{l}4(30.8) \\
38(36.9)\end{array}$ & $\begin{array}{l}9(69.2) \\
65(63.1)\end{array}$ & 0.665 \\
\hline $\begin{array}{l}\text { Marital status } \\
\text { Single } \\
\text { Married }\end{array}$ & $\begin{array}{l}8(36.4) \\
34(36.2)\end{array}$ & $\begin{array}{l}14(63.6) \\
60(63.8)\end{array}$ & 0.986 \\
\hline $\begin{array}{l}\text { Employment status } \\
\text { Employed } \\
\text { Unemployed }\end{array}$ & $\begin{array}{l}21(30.9) \\
21(43.8)\end{array}$ & $\begin{array}{l}47(69.1) \\
27(56.2)\end{array}$ & 0.156 \\
\hline $\begin{array}{l}\text { Household income (per month) } \\
\quad<\text { RM1500 } \\
\quad \geq \text { RM1500 }\end{array}$ & $\begin{array}{l}20(33.9) \\
22(39.3)\end{array}$ & $\begin{array}{l}39(66.1) \\
34(60.7)\end{array}$ & 0.549 \\
\hline $\begin{array}{l}\text { Caregiver relationship with patient } \\
\text { Spouses } \\
\text { Children } \\
\text { Others* }\end{array}$ & $\begin{array}{l}16(40.0) \\
17(32.1) \\
9(39.1)\end{array}$ & $\begin{array}{l}24(60.0) \\
36(67.9) \\
14(60.9)\end{array}$ & 0.696 \\
\hline $\begin{array}{l}\text { Duration of Caregiving (years) } \\
\leq 2 \text { years } \\
\quad>2 \text { years }\end{array}$ & $\begin{array}{l}24(38.1) \\
18(34.0)\end{array}$ & $\begin{array}{l}39(61.9) \\
35(66.0)\end{array}$ & 0.645 \\
\hline $\begin{array}{l}\text { Duration of Caregiving (hours per day) } \\
\quad \leq 8 \text { hours } \\
\quad>8 \text { hours }\end{array}$ & $\begin{array}{l}14(36.8) \\
28(35.9)\end{array}$ & $\begin{array}{l}24(63.2) \\
50(64.1)\end{array}$ & 0.921 \\
\hline $\begin{array}{l}\text { Living arrangements } \\
\text { Living with patient } \\
\text { Living apart from patient }\end{array}$ & $\begin{array}{l}33(38.4) \\
9(30.0)\end{array}$ & $\begin{array}{l}53(61.6) \\
21(70.0)\end{array}$ & 0.411 \\
\hline $\begin{array}{l}\text { Caregiver responsibilities } \\
\text { Looking after full time } \\
\text { Taking turn with others } \\
\text { Other responsibilities }\end{array}$ & $\begin{array}{l}18(38.3) \\
19(36.5) \\
5(29.4)\end{array}$ & $\begin{array}{l}29(61.7) \\
33(63.5) \\
12(70.6)\end{array}$ & 0.806 \\
\hline $\begin{array}{l}\text { Caregiver receive support from other family } \\
\text { members } \\
\text { Yes } \\
\text { No }\end{array}$ & $\begin{array}{l}34(33.3) \\
8(57.1)\end{array}$ & $\begin{array}{l}68(66.7) \\
6(42.9)\end{array}$ & 0.082 \\
\hline $\begin{array}{l}\text { Caregiver receives formal support } \\
\text { Yes } \\
\text { No }\end{array}$ & $\begin{array}{l}2(20.0) \\
40(37.7)\end{array}$ & $\begin{array}{l}8(80.0) \\
66(62.3)\end{array}$ & 0.265 \\
\hline $\begin{array}{l}\text { Caregiver taking care of others } \\
\text { Yes } \\
\text { No }\end{array}$ & $\begin{array}{l}20(33.3) \\
22(39.3)\end{array}$ & $\begin{array}{l}40(66.7) \\
34(60.7)\end{array}$ & 0.051 \\
\hline $\begin{array}{l}\text { Caregiver burden } \\
\text { No to mild } \\
\text { Moderate to severe }\end{array}$ & $\begin{array}{l}38(41.3) \\
4(16.7)\end{array}$ & $\begin{array}{l}54(58.7) \\
20(83.3)\end{array}$ & 0.025 \\
\hline
\end{tabular}

Chi square was used for the significance of the group difference

*sons or daughters in law, friends or neighbours and non-immediate relatives 
Kong $^{13}$ found that Chinese caregivers of stroke patients used primarily denial and self-blame as coping strategies; and that these strategies were also significantly associated with the caregiver's depression. It is also worth noting that there were a few data in our study, though not statistically significant, could contribute to our caregivers' possible self-blaming coping strategy. We found that caregivers who lived apart from patient; those who received any support whether informally (from family members) or formally (from paid person i.e. maid or nurse); and those who were looking after other care recipients at the same time were more depressed. This showed that there might be a sense of guilt if the caregivers were not looking after the patient themselves. As majority of the caregivers were close family members (i.e. spouse and children), this sense of responsibility is understandable as filial piety had been found to be an important factor in caregiving studies especially in Asian families. ${ }^{16}$

Among the ethnicities, the Malays had the lowest percentage of depression. Once again, this could be because of how the Malays cope. ${ }^{14}$ A study done among Malay caregivers of schizophrenia patients, noted that Malay caregivers did not complain even though their burden was high. While a qualitative study ${ }^{15}$ found that Malay caregivers coped by trying to make sense of what they were experiencing. From this we can conclude that Malay caregivers cope by accepting their fate and by reflecting. This coping mechanism could be interconnected with their Islamic beliefs since this study was carried out in Kelantan, where it is a well-known state in Malaysia for its strong Islamic teachings and practices. The majority of participants in this study were Malays and hence were Muslims, therefore would have used their religion as a mode of coping. Many researches ${ }^{17-20}$ had found that religious beliefs played an important role on how caregivers cope with their daily stress. Coping mechanisms especially in the Islamic aspect should be elicited in future studies.

\section{LIMITATION}

The results of the study are not representative of the entire population. The data represented only the stroke patients on outpatient follow-up in HUSM in Kota Bharu, Kelantan, instead of involving other health clinics in other districts or other states. The study has limitation on the design and sampling as it was a cross-sectional study and the selection of participants were based on universal sampling. There is a possibility of response bias using a guided questionnaire.

\section{CONCLUSION}

Screening for caregiver's risk depression will allow early intervention and support.

\section{ACKNOWLEDGEMENT}

The authors would like to acknowledge Universiti Sains Malaysia for supporting this study.
Funding Declaration

No funding

\section{REFERENCES}

1. World Health Organization. Facts and Figures: The World Health Report 2003 - Shaping the Future. 2003; Available from: http:// www.who.int/whr/2003/en/.

2. Rameezan BAR and Zaliha O. Functional Status of Acute Stroke Patients in University Malaya Medical Centre (UMMC), Kuala Lumpur, Malaysia. Med J Malaysia, 2005; 60:548-559.

3. Nurul Aini HM. Faktor-faktor yang mempengaruhi pemulihan pesakit strok di Kuala Lumpur. Malaysian Journal of Public Health Medicine, 2007; 7:53-58.

4. Han B and Haley WE Family Caregiving for Patients With Stroke: Review and Analysis. Stroke, 1999; 30:1478-1485.

5. Tuan Zailina TN A study on Burden Among Caregivers of Patient with Dementia in HUSM. Universiti Sains Malaysia; 2008.

6. Morimoto $\mathrm{T}$, AS Schreiner and $\mathrm{H}$ Asano Caregiver burden and health-related quality of life among Japanese stroke caregivers. Age and Ageing, 2003; 32:218-223.

7. N Azah MN, M Shah ME, Juwita S et al. Validation of the Malay Version Brief Patient Health Questionnaire (PHQ 9) among Adult Attending Family Medicine Clinics. International Medical Journal, December 2005; 12:259-263.

8. Choo WY, Low WY, Karina R et al. Social Support and Burden among Caregivers of Patients with Dementia in Malaysia. Asia Pacific J Public Health, 2003; 15:23-29.

9. Malhotra C, Malhotra R, Ostbye T et al. Depressive symptoms among informal caregivers of older adults: insights from the Singapore Survey on Informal Caregiving. International Psychogeriatrics, 2012; 24:1335-1346.

10. Tang WK et al. Emotional incontinence in Chinese stroke patients. Journal of Neurology, 2004; 251:865-869.

11. Tang WK et al. Emotional incontinence and executive function in ischemic stroke: a casecontrolled study. Journal of the International Neuropsychological Society, 2009; 15:62.

12. Wei $\mathrm{C}$ et al. Factors associated with post-stroke depression and emotional incontinence: lesion location and coping styles. International Journal of Neuroscience, 2016; 126:623-629.

13. Qiu Y, S Li. Stroke: coping strategies and depression among Chinese caregivers of survivors during hospitalisation. Journal of Clinical Nursing, 2008; 17:1563-1573.

14. Salleh MR. The burden of care of schizophrenia in Malay families. Acta Psychiatrica Scandinavica, 1994; 89:180-185.

15. Ramli FZA. Malay Caregivers' Responses to Depression among Older Adults. Advances in Natural and Applied Sciences, 2013; 7:405-412.

16. Miyawaki CE. A Review of Ethnicity, Culture, and Acculturation Among Asian Caregivers of Older Adults (2000-2012). Sage Open, 2015;1- 
18.

17. Miltiades HB, Pruchno R. The Effect of Religious Coping on Caregiving Appraisals of Mothers of Adults With Developmental

Disabilities. The Gerontologist, 2002; 42:82-91.

18. Mohd Suhaimi M, Nasrudin S, Ezarina Z et al. Cultural Influences in Mental Health Helpseeking among Malaysian Family Caregivers. Pertanika J. Soc. Sci. \& Hum., 2014; 22:1-16.

19. Chang BH, Noonan AE and Tennstedt SL. The Role of Religion/Spirituality in Coping With Caregiving for Disabled Elders. The Gerontologist, 1998; 38:463-470.

20. Azman A, Jamir Singh PS, Sulaiman J. Caregiver coping with the mentally ill: a qualitative study. Journal of Mental Health, 2016;1-6. 